\title{
The Three Robbers in Three Languages: Exploring a Multilingual Picturebook with Bilingual Student Teachers
}

\author{
The Three Robbers en tres idiomes: explorar un àlbum il·lustrat \\ multilingüe amb estudiants de magisteri bilingües
}
The Three Robbers en tres idiomas: explorar un álbum ilustrado multilingüe con estudiantes de magisterio bilingües

Esa Christine Hartmann. University of Strasbourg, France. e.hartmann@unistra.fr https://orcid.org/0000-0002-1731-6082

\author{
Christine Hélot. University of Strasbourg, France.christine.helot@gmail.com \\ https://orcid.org/0000-0001-8486-1841
}

\begin{abstract}
This study investigates translingual and multimodal teaching strategies in the context of multilingual literacy acquisition within a bilingual education program in France. It is based on a research project carried out at the Graduate School of Education of the University of Strasbourg, during the academic year 2017-2018. The purpose of our research is to analyze the student teachers' representations and attitudes towards multilingual picturebooks, and to lead them to explore the pedagogical affordances of interlingual and intersemiotic mediation in the context of a multilingual reading project built around the trilingual edition of Tomi Ungerer's The Three Robbers. The qualitative analysis of the student teachers' discourses allows us to discuss how translingual and multimodal activities give rise to a new pedagogical approach to literacy with young readers, specifically in a bilingual education context, and explain how picturebooks can foster integrated, multimodal, and translingual learning, as well as the development of biliteracy and metalinguistic awareness.
\end{abstract}

Keywords: multilingual picturebooks, bi/multiliteracy, multimodality, bi/multilingual education, translingual teaching and learning

\section{Resumen}

Este estudio investiga estrategias de enseñanza translinguísticas y multimodales en el contexto de la adquisición literaria multilingüe como parte de un programa de educación bilingüe en Francia. Está basado en un proyecto de investigación llevado a cabo en el Postgrado de la Escuela de Educación de la Universidad de Estrasburgo durante el año académico 2017-2018. El objetivo de nuestra investigación es analizar las representaciones y actitudes de los estudiantes de magisterio hacia álbumes ilustrados multilingües, y conducirles a explorar las aplicaciones pedagógicas de la mediación interlingüística e intersemiótica en el contexto de un proyecto de lectura multilingüe, construido sobre la edición trilingüe del libro The Three Robbers (Los tres bandidos) de Tomi Ungerer. El análisis cualitativo de los discursos de los estudiantes de magisterio nos permiten examinar cómo las actividades translingüísticas y multimodales dan lugar a una nueva estrategia 
pedagógica hacia la alfabetización con lectores y lectoras jóvenes, específicamente, en el contexto de una educación bilingüe, y explican cómo los álbumes ilustrados pueden promover un aprendizaje integrado, multimodal y translingüístico, además de desarrollar el conocimiento metalingüístico y una alfabetización bilingüe.

Palabras clave: álbumes ilustrados multilingües, bi/multiliteracidad, multimodalidad, educación bi/multilingüe, enseñanza-aprendizaje translingual

\section{Resum}

Aquest estudi investiga estratègies d'ensenyament translingüístiques i multimodals en el context de l'adquisició literària multilingüe com a part d'un programa d'educació bilingüe a França. Està basat en un projecte d'investigació dut a terme en el Postgrau de l'Escola d'Educació de la Universitat d'Estrasburg durant l'any acadèmic 2017-2018. L'objectiu de la nostra investigació és analitzar les representacions i actituds dels estudiants de magisteri cap a àlbums il-lustrats multilingües i conduirlos a explorar les aplicacions pedagògiques de la mediació interlingüística i intersemiòtica en el context d'un projecte de lectura multilingüe, construït sobre l'edició trilingüe del llibre The Three Robbers (Els tres bandits) de Tomi Ungerer. L'anàlisi qualitativa dels discurs dels estudiants de magisteri ens permeten examinar com les activitats translingüístiques i multimodals donen lloc a una nova estratègia pedagògica cap a l'alfabetització amb lectors i lectores joves, específicament, en el context d'una educació bilingüe, i expliquen com els àlbums poden promoure un aprenentatge integrat, multimodal i translingüístic, a més de desenvolupar el coneixement metalingüístic i una alfabetització bilingüe.

Paraules clau: àlbums il·lustrats multilingües, bi/multiliteracitat, multimodalitat, educació bi/multilingüe, ensenyament-aprenentatge translingual

«Il faut collectionner les langues parce qu'une fois qu'on a une autre langue, on comprend mieux la culture des autres. On peut s'amuser avec les langues, on peut les faire transpirer, les mettre au gril. Pour moi, un coucher de soleil, je le ressens en français, en allemand, en anglais ou en alsacien, de cette façon je peux jouir de quatre couchers de soleil à la fois, au niveau astral, c'est pas mal! » (Ungerer, 1996)

Today, the importance of teaching children's literature within the scientific context of higher education and, more specifically, within teacher education, is unquestionable. Children's literature offers windows and mirrors (Bishop, 1990) that allow us to reflect upon the complex world we live in and to make sense of our experiences inside and outside the story we read (Nikolajeva 2014). Children's literature - especially in the form of picturebooks - thus helps us construct our identity by projecting us into a playful world of reflexive imagination (Arizpe \& Styles, 2016; Sipe \& Pantaleo, 2008). However, "the skill of taking meaning from reading can only be achieved when a range of symbols that are pertinent to children are combined in 
children's literature; these may include the written, the visual, the auditory and the kinaesthetic" (Daly \& Limbrick, 2018, p.1).

In this sense, multilingual picturebooks, which induce a multimodal reading process, provide a particularly enriching pedagogical approach for literacy acquisition and development within the context of bi/multilingual education (Kümmerling-Meibauer, 2013, Mourão, 2015). As recent research has shown, multilingual picturebooks can nurture high-quality literacy learning in multilingual classrooms, based on creativity, empathy, and multicultural experience (Ibrahim, 2000; Heggernes, 2019). Be it in order to practice linguistic mediation or to foster metalinguistic awareness and multilingual literacy, teaching multilingual children's literature at university level plays an essential role in the bilingual or multilingual professional development of student teachers. More so, the discovery of the pedagogical affordances of multilingual picturebooks at university may engage student teachers in developing new pedagogical approaches to literacy teaching in multilingual classrooms through the use of children's literature.

In order to investigate translingual and multimodal teaching strategies in the context of multilingual literacy acquisition within a bilingual education program in France, we carried out a research project at the Graduate School of Education of the University of Strasbourg, during the academic year 2017-2018. The purpose of our research was to analyse the student teachers' representations and attitudes towards multilingual picturebooks and to lead them to explore the pedagogical affordances of interlingual and intersemiotic mediation in the context of a multilingual reading project using the trilingual edition of a famous picturebook, The Three Robbers by Tomi Ungerer (1962 for the first edition, published in New York). The pedagogical investigation of this picturebook, which includes three languages: Alsatian, German, and French, was guided by the following research questions:

- What are the pedagogical affordances of multilingual picturebooks in bilingual education?

- How and by which teaching strategies can these books foster multilingual literacy?

Our research method included several focus group discussions with 24 bilingual student teachers completing their first year of teaching practice in bilingual primary classrooms in France. The qualitative analysis of the multilingual reading project investigated different teaching strategies, such as interlingual and intersemiotic translation, linguistic mediation, translingual creative writing, and comparative grammar and lexicology as linguistic transfer activities. Over all, we discuss how translingual and multimodal activities give rise to a new 
pedagogical approach to picturebooks, specifically in a bilingual education context, and explain how they may encourage multilingual literacy acquisition.

Consequently, we first present a short research overview of two didactic dimensions that support our study: the trans-turn in the context of bilingual education and the pedagogical affordances of multilingual picturebooks in multilingual literacy acquisition. Second, we describe the context of bilingual education and bilingual teacher education in Alsace, France. Third, we present the context, design, and results of our research project, based on our interpretation of the pedagogical qualities of Tomi Ungerer's multilingual picturebook. Last, we reflect on a new pedagogical approach to The purpose of our research was to analyse the student teachers' representations and attitudes towards multilingual picturebooks and to lead them to explore the pedagogical affordances of interlingual and intersemiotic mediation in the context of a multilingual reading project using the trilingual edition of a famous picturebook, The Three Robbers by Tomi Ungerer multilingual picturebooks, including linguistic mediation and multimodality.

\section{Research Overview}

\subsection{The Multilingual and Trans-turn in Bilingual Education}

Multilingual education research benefits from the conceptual renewal of two subsequent "turns," the multilingual turn and the trans- turn. First, the multilingual turn (Conteh \& Meier, 2014, among others) led to a new perspective in the fields of applied linguistics. Second the updates in language acquisition, and bilingual education, by considering multilingual competence as a social factor questioning pedagogical norms, and thus as a learning resource, different from monolingual proficiency. More so, multilingual competence is now recognised as qualitatively different: "Scholars now realize that a bilingual person's competence is not simply the sum of two discrete monolingual competences added together; instead, bilingual competence integrates knowledge in two languages and is thus quantitatively different from monolingual competence" (Canagarajah, 2006, p. 591). In fact, the features of a bilingual speaker's linguistic repertoire cannot be described as a simple addition of two separate monolingual repertories but should be approached in terms of an integrated multilingual repertoire (Cummins, 2007).

Secondly, and based on the scientific acknowledgment of the mixed language practices $\mathrm{bi} /$ multilinguals negotiate in order to communicate within various linguistic communities, the trans-turn (Hawkins \& Mori, 2018) triggered an erasure of language boundaries (Cenoz \& Gorter, 
2013), and even more radically, a "disinvention of languages" (Makoni \& Pennycook, 2007) as immutable, ordinated, and separated systems that had turned out to be incompatible with the dynamic social practice of multilinguals. Evidently, the trans-turn is centred on the translanguaging theory (Garcia \& Wei, 2014), which considers the dynamic discourse practice of multilinguals as an integrative shuttling between languages, called translanguaging.

On the other hand, the described conceptual revolutions favourably enhanced the elaboration of new pedagogical approaches within the context of bilingual education. Moreover, translanguaging as a pedagogical approach in the multilingual classroom (Canagarajah, 2011; Creese \& Blackledge, 2010) refers to translingual activities that foster language awareness, linguistic mediation, and metalinguistic and intercultural competencies, helping (emergent) bilingual students construct a bilingual identity (Daly, 2014; Hélot, 2014).

According to these new approaches, bilingual education research aims to explore new

[...] bilingual education research aims to explore new pedagogical strategies to foster integrated and translingual learning, as well as the development of biliteracy and multiliteracy, especially through the creative use of children's literature pedagogical strategies to foster integrated and translingual learning, as well as the development of biliteracy and multiliteracy, especially through the creative use of children's literature (Sneddon, 2009). Indeed, the acknowledgement of mixed language practice (translanguaging) and language transfer in multilingual classrooms envisages the development of cross-linguistic or translingual teaching and learning strategies, as well as the pedagogic practice of active language transfer that allows $\mathrm{bi} /$ multilinguals to make use of their full linguistic repertoire within oral and written contexts. Hence, multilingualism is strongly connected to multiliteracy (Breuer et al., 2021; Kafle \& Canagarajah, 2015).

\subsection{Pedagogical Affordances of Multilingual Picturebooks in Multilingual Literacy} Acquisition

Following the scientific and didactic evolutions caused by the trans-turn, multiliteracy instruction now focusses on cross-linguistic or translingual approaches (Hartmann, 2020b). Consequently, children's literature can play an essential role in multilingual literacy acquisition, as illustrated in the book Children's Literature in Multilingual Classrooms (Hélot et al., 2014), with the goal of developing new pedagogical approaches to literacy teaching in multilingual classrooms through the use of children's literature. Additionally, multilingual children's literature, whether in dual language, multilingual, or translated books, offers rich possibilities to 
introduce learners to intercultural understanding, empathy, and the negotiation of hybrid identities (Bland, 2020; Short, 2009).

Yet, in order to be able to teach literacy in multilingual classrooms (Edwards, 2015), we need to imagine new pedagogical approaches and develop new visions of the teaching of reading and writing. In this sense, multilingual picturebooks particularly foster multilingual and multimodal literacy acquisition, because they can transform translanguagings into creative resources for the learning process (Kersten \& Ludwig, 2018; Hartmann, 2020a). How can we explain this link between translanguaging, which means the practice of using two or more languages concomitantly, and the acquisition of reading and writing competencies in two or more languages? The missing link would certainly be the practice of translation, which we see as mediation between two languages and two cultures. Translation explains the importance of multilingual picturebooks in multilingual literacy acquisition: multilingual picturebooks are often dual language books, presenting two linguistic versions of the same story. One of these two versions is in almost all the cases a translation (Hartmann \& Hélot, 2020). Passing from one linguistic version to the other, bilingual students learn to establish links and bridges between the two languages of the picturebook, and so, understand the connections between the different linguistic elements of their plurilingual repertoire.

Moreover, multiliteracy acquisition based on the reading of multilingual picturebooks is strongly connected to a pedagogy of multimodality (Serafini 2010), since "emergent research on literacy highlights the imaginative, interpretive, non-linear, interactive, dynamic, visual, and mobile features of communication" (Hasset \& Curwood, 2009, p. 270). The complex dynamics arising between versions of different languages (as presented in dual language books), but also between the words and images multilingual picturebooks bring to life, invites both cross-lingual and cross-semiotic reading experiences. The plurilingual and plurisemiotic (visual, textual, spatial,

The complex dynamics arising between versions of different languages (as presented in dual language books), but also between the words and images multilingual picturebooks bring to life, invites both cross-lingual and cross-semiotic reading experiences auditory, gestural) reading experience of picturebooks as an artistic and holistic performance challenges multilingual students to engage in active imagination and meaning making. "Multimodal texts include various pathways to follow parallel displays of information, extensive cross-referencing elements, evocative graphics and images that extend, an often replace, the printed word as the primary carrier of meaning" (Hasset \& Curwood, 2009, p. 271). 
Hence, multimodal picturebooks can be an excellent springboard for multilingual and multimodal literacy instruction, since they offer interactive narration, multiple perspectives, and meaning-expanding images and typology, shaping the decoding activity of the reader-interpret into a semiotic mediation process that simultaneously fosters linguistic mediation proficiency.

\section{Research Context:}

\subsection{Bilingual Education and Bilingual Teacher Education in Alsace, France}

Since the beginning of bilingual education in French public schools in 1992, the language policy that governs the organisation of bilingual education in the region of Alsace is grounded on the didactic and structural separation of the two languages of instruction, French and German. The German language within bilingual education in Alsace is considered the written standard form of the Alsatian variety (Huck, 2016), thus representing a so-called regional language and not a foreign language. The strict separation of teaching time in the French-German bilingual program in primary schools and preschools is based on the "one teacher-one language" principle that refers to Ronjat's theory (1913). In this partial immersion program (also called "50/50 immersion") leading to the binational baccalaureate diploma called Abibac (combining the German Abitur and the French Baccalauréat), all the subjects are taught half in German and half in French, whereas both the German and the French classes have to follow the totality of the French curriculum. This $50 \%$ immersion gives the emerging bilinguals enrolled in this program a high exposure to the German language, which they still have to acquire as a school language since most of the enrolled students are monolingual French children having minimal contact with the Alsatian variety.

According to our personal observations, the overall linguistic profiles of bilingual classes in Alsace greatly vary from one school to another. Some bilingual classes are composed almost exclusively of francophone pupils (emergent bilinguals), while other classes show a small number of bilingual (French-German) pupils, belonging to binational families (one French parent and one German parent) or to Alsatian families communicating in the Alsatian variety. Other classes again show multilingual learners (emergent multilinguals) with an international family background, whose family languages differ from the two school languages, French and German.

The pedagogical aim of the bilingual program in Alsace implies high literacy proficiency in French as well as in German, while the political aim entails the conservation of an expiring regional language, the Alsatian variety (Huck, 2016). According to this parity-immersion-principle (50\% immersion), all subject contents are taught through German and through French. Accordingly, one teacher is responsible for the German part of the program, and another one for the French 
part. Hence, the two languages and the subjects taught through these two languages are experienced as "two solitudes" (Cummins, 2013), as two separated linguistic spaces without communication between them, producing double or parallel monolingualism (Hélot, 2011). This top-down language policy is based on the assumption that the presence of the students' L1 (French) in the L2 class (German) represents an obstacle to the development of listening, speaking and writing proficiency in the $L 2$.

This monolingual concept of language allocation is not limited to the education of emergent bilingual students; it equally affects the education of student teachers working within the bilingual program. Whereas student teachers in charge of the French part of the program enrol in a regular monolingual teacher education program in primary education (a Master degree called "polyvalent"), student teachers assigned to the German part are indeed bilingual teachers who follow a specific program in bilingual primary education (a Master degree called "bilingual") with additional examinations in German. Curiously, although bilingual, the latter will teach all their courses only through the German language. The former, on the contrary, are considered and trained as regular mainstream teachers, although educating emergent bilingual students within a bilingual program. Both emergent bilingual students and bilingual teachers are therefore supposed to function in a monolingual mode (Hélot, 2014).

Consequently, the pedagogical practice of linguistic transfer, which may be considered as a logic outcome of the Linguistic Interdependency Hypothesis

Although bilingual education policy in Alsace leaves little room for translanguaging [...], bilingual teachers, if encouraged and supported, are well able to invent critical alternative approaches in their classrooms, which may encourage simultaneous and integrated literacy acquisition in two or more languages (Cummins, 2013), encounters numerous institutional and ideological hurdles within this context, where each language is taught in a monolingual mode, preventing emerging bilinguals from constructing a bilingual identity (Hélot, 2014). Additionally, the "one teacher-one language" policy, as well as the underlying monoglossic ideology, hinder the creation of interactional spaces where proficiency in linguistic transfer, linguistic mediation, translation, intercultural understanding, multiliteracy, and metalinguistic awareness can be

enhanced. The monolingual ideology of bilingual education in Alsace and the strict separation approach of the institutional language policy rigorously restrict the possibilities of bilingual pedagogy. Although bilingual education policy in Alsace leaves little room for translanguaging (representing, as we have seen, both the social practice of bilingual speakers and a pedagogical approach to bilingual education), bilingual teachers, if encouraged and supported, are well able 
to invent critical alternative approaches in their classrooms, which may encourage simultaneous and integrated literacy acquisition in two or more languages.

\section{Research Project}

\subsection{Exploring a Multilingual Picturebook in Bilingual Teacher Education}

As our research overview has shown, multilingual picturebooks represent a rich multimodal learning resource for bi/multilingual literacy acquisition in multilingual and multicultural classrooms. The bilingual education context in Alsace particularly invites the didactic and pedagogic exploration of multilingual picturebooks written by multilingual Alsatian authors, since they reflect the pluralistic cultural identity of bi/multilingual learners. We therefore chose to work with a picturebook by Tomi Ungerer (1931, Strasbourg, France - 2019, Cork, Ireland), a multilingual Alsatian painter, illustrator and author, whose famous picturebooks fascinate both children and adults. Tomi Ungerer worked in New York, Canada, Ireland, and France. He published over 140 books in English, French, German, and Alsatian, that were translated into more than thirty languages, ranging from his celebrated children's stories to controversial volumes of social satire.

\subsection{General Objectives of the Research Project}

In order to investigate new pedagogical approaches for multilingual literacy acquisition, we designed a multilingual reading project within our German didactics course for bilingual student teachers at the Graduate School of Education of the University of Strasbourg (Bilingual Master Program, academic year 2017-2018). The objective of this project was to make bilingual teachers aware of the pedagogic affordances of multilingual picturebooks in bilingual education. More specifically, this project targeted the didactic elaboration of integrated and translingual teaching strategies for biliteracy instruction in bilingual primary classrooms in Alsace.

\subsection{Academic Profile of the Participants}

At the time of the project, the student teachers were in the middle of the second year of the Bilingual Master program for bilingual primary teacher candidates, which follows a three-year Undergraduate Program (called "Licence" and equaling the Bachelor's Degree) in different subject areas. Simultaneously, the student teachers were accomplishing their teacher training practice in bilingual primary classrooms two days a week, where they were in charge of the German part of the curriculum. The student teachers' discourses hence reflect their representations and experiences as young teachers in bilingual primary classrooms in Alsace. During their first year of the Master Program, the participants in our research had already taken 
some course units in bilingual education didactics, but at the time of the project, they had not yet acquired any academic knowledge about biliteracy instruction.

\subsection{Linguistic Profile of the Participants}

Although all of the student teachers participating in our project showed a bilingual FrenchGerman profile, their bilingual repertoire turned out to be highly diverse. Indeed, the linguistic resources and competences of bilingual teachers in Alsace reflect the multiple and complex linguistic profiles of the bilingual primary classrooms they teach. While many bilingual teachers belonged to binational French-German families or to Alsatian speaking families and had attended the bilingual track to the Abibac (French-German Baccalaureate Degree), others completed a Bachelor's Degree in German studies at a French university inside or outside of the region of Alsace, so that their bilingualism could be mostly considered as an academic outcome. Another group of the student teachers had completed a successful Erasmus exchange in Germany, Switzerland, or Austria during one or two semesters, which allowed them to acquire sufficient proficiency in the German language to enroll in the bilingual teacher education program. Another group again was raised in an international and multilingual academic and familial environment in Germany or France, and was now attending the selective integrated bilingual study program of the French-German University, alternating semesters in French and German universities throughout the curriculum. Lastly, some bilingual student teachers with high proficiency in German grew up as children of German cross-border commuters from the other side of the Rhine River. Last of all, a very small number of the student teachers consists of German and German speaking students, who wish to gain experience in the French education system for personal reasons.

\subsection{Tomi Ungerer's The Three Robbers as a Trilingual Picturebook}

The multilingual book we chose to work with is the famous story of The Three Robbers (1962). The trilingual edition Die drei Raiwer (2008) unites the translations in the three languages of Alsace: Alsatian, French and German. Studying the picturebook of a multilingual Alsation author represents an excellent strategy for acquiring multimodal and multilingual literacy, but also for constructing a bilingual identity and gain a deeper understanding of bilingualism and biculturalism. With his famous statement "Je n'ai pas de langue maternelle. J'ai seulement plusieurs langues fraternelles" [I don't have a mother tongue. I only have several fraternal languages] (Ungerer, 1996, our translation), Tomi Ungerer deconstructs the ideology of a unique mother tongue and opens the path towards a multilingual and multicultural identity. Interestingly, Tomi Ungerer calls the concept and practice of multilingualism an interlingual 
traffic: "Quand on est trilingue, on a une possibilité bien plus grande de jouer avec les mots, on peut trafiquer d'une langue à une autre" [When one is trilingual, one has a much greater possibility to play with words; one can traffic from one language to another] (Ungerer, 1996, p. 49, our translation). The metaphor traffic refers to the two main concepts of translanguaging: shifting between languages and cultures, tampering with the monolingual norm, and negotiating a multilingual and multicultural identity.

The trilingual book Die drei Raiwer - Les trois brigands - Die drei Räuber [The Three Robbers] illustrates such a negotiation of linguistic and cultural

With his famous statement "Je n'ai pas de langue maternelle. J'ai seulement plusieurs langues fraternelles" [I don't have a mother tongue. I only have several fraternal languages], Tomi Ungerer deconstructs the ideology of a unique mother tongue and opens the path towards a multilingual and multicultural identity identity. Although it was originally written in English by Tomi Ungerer and published in New York in 1962, the trilingual book edited in Strasbourg (Ungerer, 2008) only presents three languages - Alsatian, French, and German - as a symbolic synthesis of the region's polyphony, without incorporating the original language the story was written in. The concept of this multilingual book, titled Tomiphonie (by the editor who wrote the introduction), recalling Bakhtin's (1970) famous "polyphonie," represents not only a metaphor of the concept of linguistic plurality, but also a mirror of Ungerer's linguistic identity, which is presented as an Alsatian identity, crystallizing the fusion of three languages: Alsatian, French, and German. Accordingly, the Alsatian translation accomplished in the trilingual edition by an Alsatian poet and writer, Robert Werner, embodies this polyphonic fusion of French and German within the Alsatian dialect, since this translation actually arose from both the French (Ungerer, 1968) and the German (Ungerer, 1963) versions. The trilingual edition thus becomes a symbol of the linguistic and cultural identity of the Alsatian region, as told in the introduction to the book: "Like in everyday life in Alsace, the three languages luckily cohabit on the same page, encouraging stimulating linguistic activities" (Introduction by the editor, our translation).

\section{Research Method and Design}

In our research project, 24 bilingual student teachers enrolled in our German didactics course formed eight groups of three students that discussed the reading of the trilingual edition of The Three Robbers, to answer the following questions: "Could you imagine reading this trilingual picturebook with your pupils? How would you read it? Which activities could accompany this 
reading in order to build bridges between the different languages of the book/classroom?" In

Could you imagine reading this trilingual picturebook with your pupils? How would you read it? Which activities could accompany this reading in order to build bridges between the different languages of the book/classroom?

this way, eight group discussions took place within the framework of two course units in December 2017 and January 2018. The outcome data of these focus group discussions were recorded as text documents (word documents) or audio documents (mobile phone recordings) sent to our email address. The discussions, deliberations, and proposals of the student teachers in this context served as data for the qualitative analysis presented below.

The qualitative analysis of the student teachers' discourses follows three categories that we indicated inductively: (1) Possibilities of implementation of translingual teaching strategies in the context of the prevailing language policy; (2) Status and interaction modalities of the different languages displayed in the picturebook; (3) Creation of a repertoire of translingual teaching strategies for multiliteracy instruction.

\section{Research Results:}

\subsection{Translingual Teaching Strategies for The Three Robbers}

How could Tomi Ungerer's trilingual picturebook be read in a bilingual primary class in Alsace and, more specifically, during the German class, from which language alternating and mixing is officially banned, as a consequence of the institutional language policy? On the one hand, the discourse analysis of the group discussions reveals some student teachers' preference for an alternate reading in the different languages of the book, as well as an alternate distribution of the latter. This language alternation, which implies language separation, means that the student teachers would take advantage of the "one teacher-one language" principle to split the story into different chapters that would be read each one in one single language. In this sense, language alternation would take place between different chapters of the story, according to a monolingual approach.

On the other hand, some student teachers show interest in linguistic transfer revealing the similarities between Alsatian and German lexis, as well as interferences of the French syntax within the Alsatian text. These cross-linguistic activities indicate an integrated and translingual approach. Lastly, the student teachers observe the status of each language within the visual presentation of the page, as well as the intersemiotic relationship between text and image, between language and visual representation, the latter dominating, interconnecting and 
"translating" all three languages (French, German, Alsatian) according to an intersemiotic approach.

Creative plurilingual pedagogy also means developing intercultural communication proficiency, such as understanding different interpretation possibilities of moral values transmitted in the story (kindness vs. ferocity, outlaws vs. justice, richness vs. poverty), and, overall, Ungerer's "Alsatian humour," which appears to be essentially translingual. However, translingual approaches do not end here: the participants of this project multiply multilingual writing, speaking and theatre performances, which crystallise other forms of intersemiotic transfer.

As expected, the "one teacher-one language" policy dominates and sometimes overrules the pedagogical possibilities of the trilingual reading, but does not impede the creation of innovative pedagogic approaches that highlight translingual activities such as linguistic transfer and mediation, metalinguistic analysis, as well as creative multimodal tasks, all fostering biliteracy acquisition.

\subsection{Translingual Activities or Language Alternation?}

How to fit into the "one teacher-one language" policy and the separation of languages, time and subjects when reading a trilingual story in a bilingual mode? The solution proposed by the trainee teachers would be to apply the method of consecutive language alternation. Consecutive language alternation implies the practice of alternating languages and teachers instead of mixing languages by an only teacher. "The book could best be explored together by the two collaborating teachers (French teacher and German teacher). Such collaboration would create coherence between the two parts of the bilingual programme. The French teacher would be responsible for the French translation of the story, and the German teacher for the German translation." This kind of language alternation produced by parallel readings in two languages implies forms of tandem teaching: "This trilingual book could illustrate bilingualism: both teachers could read it in a parallel way, each one in his/her language. That is, the German teacher reads the German text, and the French teacher reads the French text. This way, the students will get to know the same story in two languages." In the words of another group: "One day, two pages of the German text could be read, the next day, two pages of the French text could follow, the book travelling between the two classes." In this sense, the French version would adopt an initiation function, facilitating the subsequent entry into the German text: "We certainly could read a trilingual book in the bilingual class, because students could better understand the story. It is very important to build a connexion between the two languages for conveying the meaning of the story. The French teacher could begin with the reading. The first 
part of the story is quite complicated; therefore, it would be more logical to first read and explain it in French."

Only one suggestion seems to refer to consecutive language alternation by the same teacher: "The story of this book could be discovered and read in three languages: the first page in Alsatian, the second page in French and the third page in German. This rotation from one page to another would allow the students who do not understand German nor Alsatian to find elements corresponding to their first language every third page, which might help their understanding of the story."

These possibilities of consecutive language alternation based on the separate reading of the French and the German texts in Tomi Ungerer's trilingual picturebook can be considered as a constructive compromise for fitting into the prevailing language policy. Yet, they seem to miss the important linguistic and cognitive benefits of simultaneous translingual reading, as shown in the following sections.

\subsection{Alsatian and German: Inter-comprehension Activities}

Language awareness and inter-comprehension activities are connected to the discovery of the story's multilingual context and text and the nature of the three languages presented in the book. "The teacher could begin this project by reading aloud the Alsatian text and ask the students if this language makes them think of something... if they understand something... If the students discover that the language the story was read in is the Alsatian variety, the teacher could show them the numerous similarities between Alsatian and German, but also between Alsatian and French, because Alsatian is a mixture of both."

The status of the Alsatian variety within the trilingual book undoubtedly leads to the analysis of the linguistic presentation and context of the story, but also addresses linguistic comparison: "The German and the French part of the text displayed on the page is almost identical since they represent quite literal translations of the Alsatian text, which is written in much greater typographical letters. Consequently, the Alsatian text appears to be the original text, while the French and German texts have to be seen as subordinated translations"; "This trilingual children's book emphasises the Alsatian variety, written in greater typographical letters and thus consuming more space on the page. The title of the book is only written in Alsatian, without translation. The translation into German and French is supposed to help understand the Alsatian text. This trilingual book offers the opportunity to construct linguistic links between German and the Alsatian variety." 
Over all, student teachers became aware of the prominence given to the Alsatian language and proposed a reading of the story in this language in order to subsequently compare it with standard German and to detect similarities and differences. In the words of the teachers: "The book is meant to discover the Alsatian variety. Students could try to read and to understand the Alsatian text, by referring to the German and the French translation." These inter-comprehension activities allow

The book is meant to discover the Alsatian variety. Students could

try to read and to understand the Alsatian text, by referring to the German and the French translation students to establish links between parented languages such as Alsatian and German, but also to connect the academic school language to the familiar regional variety: "The most important language of this multilingual book is the Alsatian variety. It would be interesting to read this story in Alsatian as well. Afterwards, the students could hear, discover and detect the similarities and the differences between standard German and the Alsatian variety."

\subsection{French and German: Linguistic Mediation}

Another group of student teachers focused on French and German, the two languages of the bilingual program being presented to learners together in a book, as offering a support for reading comprehension. For example, "the students have the possibility to look in the French translation for a word they do not know in German and to find its meaning: as for example Räuber/brigands".

In fact, "constructing links or bridges between languages" refers to interlinguistic comparison and transfer as a cognitive activity. Linguistic mediation is meant to enhance the comprehension and semantic analysis of the story, as shown in the following suggestions. "The side-by-side coexistence of the French and the German translations of the Alsatian text facilitates linguistic mediation: students can look in the parallel French translation for a word they don't know in the German text and get the meaning of it."

As "language mixing or alternating by the teacher" is not recommended by student teachers trying to fit into the one teacher-one language policy, their "student experts" play an active part in linguistic mediation, using linguistic transfer to foster the understanding of the story by their fellow students. "The students will adopt the important part of the mediation between languages: they are the interpreters of the two language teachers (German and French). Likewise, student experts will reformulate and explain the plot of the story to those who do not understand." 
But even when translation is seen as creating a bridge between different languages, other student teachers warned of the danger of using translation too often, lest it endangers the acquisition of German: "Being able to go from one language to another could help to build bridges between the different languages. However, in the daily context of teaching through German, working on the French text should remain rare and clearly motivated, otherwise the learners will not make the effort to learn the German language." This statement is not surprising; it is consistent with the belief in the one language-one teacher policy being the best strategy for learning German. It also shows a lack of understanding of young learners' motivations in learning an additional language.

\subsection{Illustrations and Intersemiotic Translation: Towards Multimodal Reading}

Unsurprisingly, some student teachers showed a clear preference for intersemiotic translation, focusing on the central role of the illustrations for comprehension of the text in one language or the other, precisely because it allowed them to avoid the use of interlingual translation and to keep to the one language - one teacher policy. For example, they explained: "Only one picture corresponds to the three texts, thus showing readers that the three languages mean the same thing. The picture is as important as the text and takes the largest space on the page." Or again, "the role of the pictures is rather important: the reader can use the pictures to understand the meaning of the text. Pictures are explanatory. We also have the possibility to read the story in one language only: the students are going to understand the text with the pictures, without understanding the language in which the text was read." The second quote points to the possibility of reading the text in one language only, therefore avoiding any form of language mixing or contact between the three languages displayed in the book. In other words, this trilingual book would be read as a monolingual book and intersemiotic translation used to develop reading comprehension in one language only.

Consequently, if the student teachers prefer intersemiotic transfer to linguistic transfer, they give the text-image relationship a greater pedagogical impact in the process of comprehension: "The images can be perceived and used as mediation to language and can assist the understanding of the text. Instead of using translation, it would be preferable to refer to the images, in order to see if they help reveal the meaning of the story, given that the pictures dominate the text." Lastly, Tomi Ungerer's pictures are perceived as a valuable tool for lexical acquisition: "In order to acquire new vocabulary, the students could link several images of the book to several new words." 


\subsection{Metalinguistic Activities}

Taking a different approach to this monolingual view of translation, a further group of student teachers was at once aware of the affordances of a trilingual text for metalinguistic activities, and for students to be given concrete examples of multilingualism. In fact, interlinguistic comparison in the form of comparative (contrastive) grammar, as well as the development of metalinguistic proficiency, cannot be avoided when reading a trilingual book: "The multilingual book is not necessarily fitted for the German class, since, generally, the decoding of the German text should be made through the images and not always through the French translation. Nevertheless, recent research recommends constructing links between the languages taught, as well as to use a metalanguage."

Others suggested that the learners themselves be educated to reflect on the similarities between the three languages and taught to decode some words in the German text: "The students should establish the similarities between the three languages. The teacher could read the Alsatian text, and the students could mark the words they recognize in the German text." Language awareness leads to language comparison: "This trilingual book makes the students aware that the same word can exist in several languages. The next step could be reading the Alsatian text and its translations into German and French and having the students compare them in order to examine the similarities and the differences between the three languages." Finally, language comparison implies reflexion on the functioning of language as metalinguistic thinking: "The students could try to detect the same words in the different languages; for example: Alsatian: gschicht, German: Geschichte, French: histoire. They will also discover that the capital letters of the German nouns do not apply to the Alsatian variety."

\subsection{Multilingual Literacy Activities}

Furthermore, some student teachers saw the possibility with the trilingual text of carrying out narrative analysis in a bilingual mode. They suggested "the students could study the use of grammatical and semantic connectors through this story, used to create the narrative progression: Es war einmal / II était une fois (beginning of the story), Der Erste .... Der Zweite... Der Dritte / Le premier... Le deuxième... Le troisième (presentation of the three robbers), as well as Zum Schluss / À la fin, announcing the ending of the story."

Finally, Tomi Ungerer's trilingual book gave rise to the idea of proposing a multilingual creative writing project, based on a new version of The Three Robbers. This multilingual text would incorporate all the languages spoken by the children in a class, who would also illustrate the text and invent a new ending. In the words of the student teachers: "As a follow-up activity, students 
could complete a multilingual writing project and write a multilingual story using all the different languages spoken in their class, based on the story of The Three Robbers. The students could rewrite the same story with all the languages they practice and paint their pictures to accompany the text or invent new multilingual chapters that could follow the end of the story." This most creative proposition is another form of interlinguistic transfer, essential to multilingual literacy acquisition. This sort of transfer can give multilingual children the opportunity to be the authors of their own texts and to make full creative use of their multilingual competence.

We surely must appraise the courage of conducting such a multilingual writing exercise where textual trans/anguaging is at work since the actual understanding of the development of biliteracy is still dominated by a mono-linguistic approach. Indeed, creative transposition activities could represent another form of intersemiotic and interlinguistic transfer, as suggests another group: "The students could act a little scene of the story in order to practice the pronunciation of the language and to give meaning to the text read, for example, the scene of page 3-4."

\subsection{Multimodal and Intercultural Activities}

The reading of Tomi Ungerer's trilingual picturebook could be enriched thanks to an intercultural and multimodal interconnection with other creations around the robber-theme, such as a song, a movie and tales. Let's quote the student teachers' proposition: “The Three Robbers could be linked to the stories of Robin Hood and the Arabian tale Ali Baba and the 40 Thieves." This intercultural approach could be widened by a multimodal one, as pursues the participant: "We could watch the movie of The Three Robbers and listen to (and sing) The Three Robbers song."

Two multimodal suggestions are intended to enhance the lexical repertoire in German: "We could describe the pictures of the book in German and learn new vocabulary. We could also listen to the audiobook in German and to the sounds that accompany the reading and that explicit the different weapons of the Robbers, for example."

\section{Conclusions and Perspectives: Towards a New Pedagogical Approach to Multilingual Picturebooks}

Our research project based on the trilingual edition of Tomi Ungerer's The Three Robbers allowed us to reflect on a new pedagogical approach to multilingual picturebooks, emphasising linguistic mediation and multimodality. In multilingual picturebooks, the building of bridges between different languages is complemented by the shifting between different media, especially between text and image. In picturebooks, images play the most significant part in 
meaning making, as they settle and narrate the story and make the content palpable. In The Three Robbers, text and images are complementary, as for example in the last page of the story, where the meaning is purely figurative, since it arises from the visual analogy between the robbers' hats and the form of the three towers.

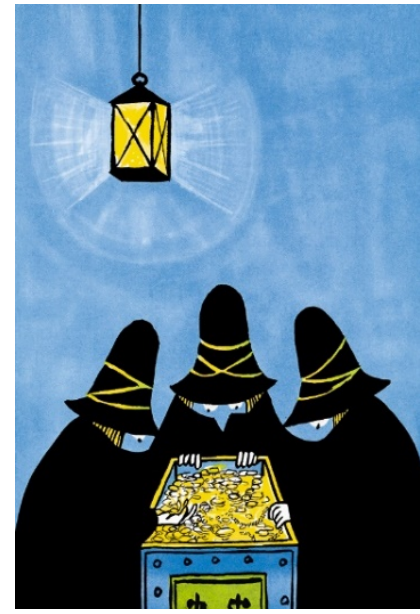

Figure 1. Meaning arising from visual analogy 1: Tomi Ungerer, Die drei Räuber

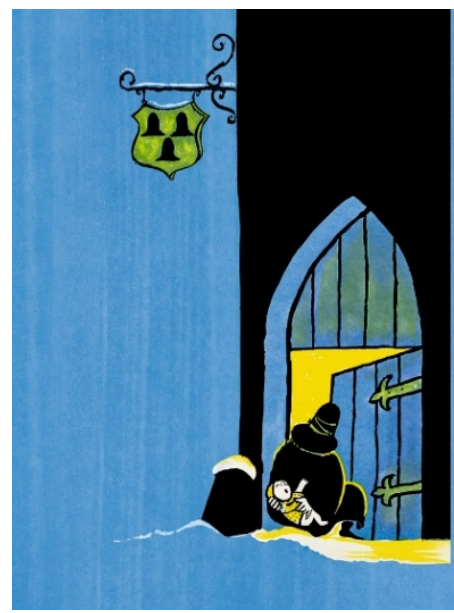

Figure 2. Meaning arising from visual analogy 2:

Tomi Ungerer, Die drei Räuber

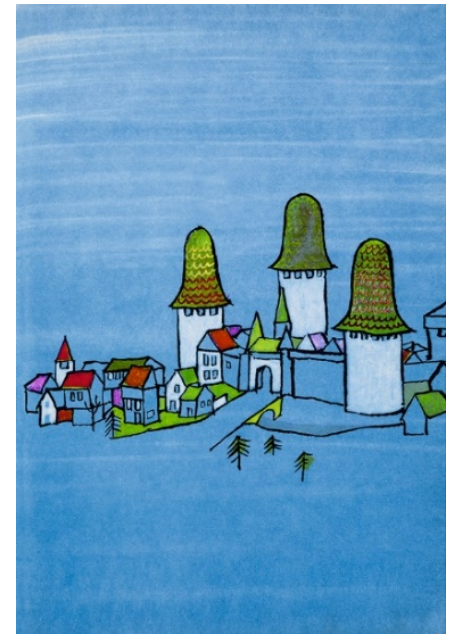

Figure 3. Meaning arising from visual analogy 3: Die drei Räuber 1

This visual analogy, which becomes a key image, is also present on the emblem of the robbers' castle. Discovering Tomi Ungerer's picturebook therefore means to read in an intermedial or multimodal way, and to decrypt the secret links between pictures and text. In this context, learning to read also means learning to decode, understand and interpret the marvellous pictures, and to combine the information they convey with the information delivered by the

\footnotetext{
${ }^{1}$ Three figures from Tomi Ungerer Die drei Räuber Copyright @ 1963, 1967 Diogenes Verlag AG Zürich
} 
three linguistic versions: French, German, and Alsatian. Consequently, picturebooks belong to the category of multimedia, calling for a multimodal approach of literacy teaching.

Our research argues for the use of multilingual picturebooks for the development of multilingual literacy in bilingual education, and more importantly, within the teacher education program for bilingual teachers at university. Such books could not exist without translation; therefore, they are the best examples of the mediation competence and intercultural understanding $\mathrm{bi} /$ multilinguals develop through their knowledge of several languages.

For teachers, the pedagogical affordances of multilingual picturebooks in bilingual pedagogy

Our research argues for the use of multilingual picturebooks for the development of multilingual literacy in bilingual education, and more importantly, within the teacher education program for bilingual teachers at university. should be exemplified through creative projects, reassuring them that functioning in a multilingual mode is not detrimental to their students' bilingual acquisition. We also hope to have shown in this article that student teachers are well able to become creative agents of change in bilingual classrooms, once they have understood that strictly separating languages in their literacy teaching is not the most productive approach for their students to develop their bilingual identity.

Multiliteracy teaching means teaching to read and write in several languages and in different semiotic modes: multilingual picturebooks are thus a perfect support for multimodal and multilingual literacy acquisition. Presently, ongoing research projects are trying to improve the translingual teaching strategies presented in this study by testing them in bilingual primary classrooms, in order to elaborate innovating pedagogical approaches for the creative reading of multilingual picturebooks.

\section{References}

Arizpe, E. \& Styles, M. (2016). Children reading picturebooks: Interpreting visual texts. Routledge.

Bakhtin, M. (1970). La poétique de Dostoïevki. Seuil.

Bishop R. S. (1990). Mirrors, windows, and sliding glass doors. Perspectives: Choosing and using books for the classroom, 6(3), 9-11.

Bland, J. (2020). Using literature for intercultural learning in English language education. In M. Dypedahl \& R. Lund (Eds.), Teaching and learning English interculturally (pp. 69-89). Cappelen Damm Akademisk.

Breuer, E., Lindgren, E., Stavans, A., Steendam, E. (2021). Multilingual literacy. Multilingual Matters.

Canagarajah, S. (2006). Toward a writing pedagogy of shuttling between languages: Learning from multilingual writers. College English, 68(6), 589-604. 
Canagarajah, S. (2011). Translanguaging in the classroom: Emerging issues for research and pedagogy. Applied Linguistics Review, 2, 1-28.

Cenoz J. \& Gorter, D. (2013). Toward plurilingual approach in English language teaching: Softening the boundaries between languages. TESOL Quarterly, 47(3), 591-599.

Conteh, J. \& Meier, G. (2014). The multilingual turn in languages education: Opportunities and challenges. Multilingual Matters.

Creese, A. \& Blackledge, A. (2010). Translanguaging in the bilingual classroom: A pedagogy for learning and teaching? Modern Language Journal, 94(1), 103-115.

Cummins, J. (2007). Rethinking monolingual instructional strategies in multilingual classrooms. Canadian Journal of Applied Linguistics, 10(2), 221-240.

Cummins, J. (2013). Current research on language transfer: Implications for language teaching policy and practice. In P. Siemund (Ed.), Multilingualism and language diversity in urban areas (pp. 289-304). Benjamins.

Daly, N. (2014). Windows between worlds: Loanwords in New Zealand children's picture books as an interface between two cultures. In C. Hélot, R. Sneddon \& N. Daly (Eds.), Children's literature in multilingual classrooms: From multiliteracy to multimodality (pp. 35-46). Trentham Books.

Daly, N. (2018). The linguistic landscape of English-Spanish dual language picturebooks. Journal of Multilingual and Multicultural Development, 39(6), 556-566.

Daly \& Limbrick (2018). Introduction. In N. Daly, L. Limbrick, P. Dix (Eds.), Children's literature in a multiliterate world (pp. 1-6). Trentham Books.

Daly, N., Limbrick, L. \& Dix, P. (Eds.) (2018). Children's literature in a multiliterate world. Trentham Books.

Edwards, V. (2015). Literacy in Bilingual and Multilingual Education. In W.Wright, S. Bown \& O. Garcia (Eds.), The handbook of bilingual and multilingual education (pp. 75-91). Wiley-Blackwell.

Garcia, O. \& Wei, L. (2014). Translanguaging. Language, bilingualism and education. Macmillan.

Hartmann, E. (2020a). Les albums bilingues: de la traduction à la bilittéracie. Nouveaux Cahiers d'Allemand. Revue de linguistique et de didactique, 38(2), 193-212.

Hartmann, E. (2020b). Experimenting translingual approaches and translanguaging in the bilingual classroom. In O. Mentz \& K. Papaja (Eds.), Focus on language. Challenging Language learning and language teaching in peace and global education (pp. 91-113). LIT Verlag.

Hartmann E. \& Hélot C. (2020). Pedagogical affordances of translation in bilingual education. In S. Laviosa \& M. Gonzáles-Davies (Eds.), The Routledge handbook of translation and education (pp. 95108). Routledge.

Hasset, D. \& Curwood, J (2009). Theories and practices of multimodal education: The instructional dynamics of picture books and primary classrooms. The Reading Teacher, 63(4), 270-282.

Hawkins, M. \& Mori, J. (2018). Considering "trans-"perspectives in language theories and practices. Applied Linguistics, 39(1), 1-8.

Heggernes, S. (2019). Opening a dialogic space: Intercultural learning through picturebooks. Children's Literature in English Language Education, 7(2), 37-60.

Hélot, C. (2011). Children's literature in the multilingual classroom. In C. Hélot \& M. O'Laoire (Eds.), Pedagogy of the possible: Language policy in the multilingual classroom (pp. 42-64). Multilingual Matters.

Hélot, C. (2014). Rethinking bilingual pedagogy in Alsace: Translingual writers and translanguaging. In A. Blackledge \& A. Creese (Eds.), Heteroglossia as practice and pedagogy (pp. 217-238). Springer. 
Hélot, C., Sneddon, R. \& Daly, N. (Eds.) (2014). Children's literature in multilingual classrooms. From multiliteracy to multimodality. Trentham Books.

Huck, D. (2016). L'espace scolaire comme espace d'enjeux sociolinguistiques et idéologiques: I'allemand et l'alsacien en Alsace. In C. Hélot \& J. Erfurt (Eds.), L'Éducation bilingue en France. Politiques linguistiques, modèles et pratiques (pp. 154-167). Lambert-Lucas.

Ibrahim, N. (2020). The multilingual picturebook in English language teaching: Linguistic and cultural identity. Children's Literature in English Language Education, 8(2), 12-38.

Kafle, M. \& Canagarajah, S. (2015). Multiliteracies, pedagogies, and academic Literacy. In W. Wright, S. Bown \& O. Garcia, (Eds.), The handbook of bilingual and multilingual education (pp. 241-252). WileyBlackwell.

Kersten, S. \& Ludwig, C. (2018). Translanguaging and multilingual picturebooks: Gloria Anzaldúa's "Friends from the other side/Amigos del otro lado". Children's Literature in English Language Education, 6(2), 7-27.

Kümmerling-Meibauer, B. (2013). Multilingualism and children's literature. Bookbird: A Journal of International Children's Literature, 51(3), iv-x.

Makoni, S. \& Pennycook, A. (2007). Disinventing and reconstituing languages. Multilingual Matters.

Mourão, S. (2015). The potential of picturebooks with young learners. In J. Bland (Ed.), Teaching English to young learners: Critical issues in language teaching with 3-12 year olds (pp. 199-217). Bloomsbury Academic.

Nikolajeva, M. (2014). Reading for learning. Cognitive approaches to children's literature. J. Benjamins.

Ronjat, J. (1913). Le développement du langage observé chez un enfant bilingue. Champion.

Serafini, F. (2010). Reading multimodal text: Perceptual structural and ideological perspectives. Children's Literature in Education, 41, 85-104.

Short, K. (2009). Critically reading the word and the world: Building intercultural understanding through literature, Bookbird. A Journal of International Children's Literature, 47(2), p. 1-10.

Sipe, L. \& Pantaleo, S. (Eds.) (2008). Postmodern picturebooks: Play, parody, and self-referentiality. Routledge.

Sneddon, R. (2009). Bilingual books - Biliterate children: Learning to read through dual language books. Trentham Books.

Ungerer, T. (1962). The three robbers. Atheneum.

Ungerer, T. (1963). Die drei Räuber. Diogenes.

Ungerer, T. (1968). Les trois brigands. Ecole des Loisirs.

Ungerer, T. (2008). Die drei Raiwer. La Nuée Bleue.

Ungerer, T. (2016). Tomi Ungerer par Tomi Ungerer. La revue des livres pour enfants, 171, $n^{\circ}$ spécial "Autour de Tomi Ungerer ", 48-57.

How to cite this paper:

Hartmann, E. C., \& Hélot, C. (2021). The Three Robbers in Three Languages: Exploring a Multilingual Picturebook with Bilingual Student Teachers. Journal of Literary Education, (4), 174-195. https://doi.org/10.7203/JLE.4.21023 